\title{
Determinants of maternal pregnancy one-carbon metabolism and newborn human DNA methylation profiles
}

\author{
Nina H van Mil ${ }^{1,2,3}$, Marieke I Bouwland-Both ${ }^{1,3}$, Lisette Stolk ${ }^{4}$, Michael M P J Verbiest ${ }^{4}$, \\ Albert Hofman ${ }^{5}$, Vincent W V Jaddoe ${ }^{1,5,6}$, Frank C Verhulst ${ }^{2}$, Paul H C Eilers ${ }^{7}$, \\ Andre G Uitterlinden ${ }^{4,5}$, Eric A P Steegers ${ }^{3}$, Henning Tiemeier ${ }^{2,5,8}$ and \\ Régine P M Steegers-Theunissen ${ }^{3,+}$ \\ ${ }^{1}$ The Generation $R$ Study Group, ${ }^{2}$ Department of Child and Adolescent Psychiatry, ${ }^{3}$ Department of Obstetrics \\ and Gynecology, ${ }^{4}$ Department of Internal Medicine, ${ }^{5}$ Department of Epidemiology, ${ }^{6}$ Department of Paediatrics, \\ ${ }^{7}$ Department of Biostatistics and ${ }^{8}$ Department of Psychiatry, Erasmus MC, University Medical Centre Rotterdam, \\ Dr Molewaterplein 50, 3015 GE Rotterdam, The Netherlands
}

Correspondence should be addressed to R P M Steegers-Theunissen; Email: r.steegers@erasmusmc.nl

${ }^{\dagger} \mathrm{R}$ P M Steegers-Theunissen is now at Department of Obstetrics and Gynaecology, Erasmus MC, University Medical Centre Rotterdam, The Netherlands

\begin{abstract}
Maternal one-carbon (1-C) metabolism provides methylgroups for fetal development and programing by DNA methylation as one of the underlying epigenetic mechanisms. We aimed to investigate maternal 1-C biomarkers, folic acid supplement use, and MTHFR C677T genotype as determinants of 1-C metabolism in early pregnancy in association with newborn DNA methylation levels of fetal growth and neurodevelopment candidate genes. The participants were 463 mother-child pairs of Dutch national origin from a large populationbased birth cohort in Rotterdam, The Netherlands. In early pregnancy (median 13.0 weeks, 90\% range 10.4-17.1), we assessed the maternal folate and homocysteine blood concentrations, folic acid supplement use, and the MTHFR C677T genotype in mothers and newborns. In newborns, DNA methylation was measured in umbilical cord blood white blood cells at 11 regions of the seven genes:

NR3C1, DRD4, 5-HTT, IGF2DMR, H19, KCNQ1OT1, and MTHFR. The associations between the 1-C determinants and DNA methylation were examined using linear mixed models. An association was observed between maternal folate deficiency and lower newborn DNA methylation, which attenuated after adjustment for potential confounders. The maternal MTHFR TT genotype was significantly associated with lower DNA methylation. However, maternal homocysteine and folate concentrations, folic acid supplement use, and the MTHFR genotype in the newborn were not associated with newborn DNA methylation. The maternal MTHFR C677T genotype, as a determinant of folate status and 1-C metabolism, is associated with variations in the epigenome of a selection of genes in newborns. Research on the implications of these variations in methylation on gene expression and health is recommended.

Reproduction (2014) 148 581-592
\end{abstract}

\section{Introduction}

Epigenetics has gained interest as it is proposed to be an interface between the dynamic environment and the genome. DNA methylation, one of the best known epigenetic mechanisms, is essential for embryogenesis, fetal programing, and development (Waterland \& Jirtle 2004, Shames et al. 2007).

One-carbon (1-C) metabolism plays a crucial role in DNA methylation as it determines the flux of methylgroups toward synthesis or methylation of DNA. Folate and choline are the main sources of methyl groups in 1-C metabolism that enables the conversion of homocysteine into methionine, which in turn leads to the production of $S$-adenosylmethionine $(\mathrm{SAM})$ as a principal methyldonor for DNA methylation (Crider et al. 2012). The 1-C metabolism is influenced by common polymorphisms, in particular the methylene tetrahydrofolate-reductase (MTHFR) C677T polymorphism, which interacts with the folate status and DNA methylation, in particular in situations of folate deficiency (Crider et al. 2011). In addition to genetic variants, dietary folate intake, folic acid supplement use, lifestyle, and medication are known to influence the folate status (Steegers-Theunissen et al. 2013). Our group previously reported higher levels of insulin-like growth factor 2 
(IGF2) DMR methylation in white blood cell DNA from very young children after periconceptional exposure to maternal folic acid supplement use (Steegers-Theunissen et al. 2009). This is supported by human and animal studies also emphasizing the importance of the 1-C pathway in fetal programing (Gueant et al. 2013, Steegers-Theunissen et al. 2013).

A low maternal folate status during pregnancy has been associated with an increased risk of pregnancy complications, intrauterine growth restriction, and developmental disorders including learning disabilities and emotional problems (Bergen et al. 2012, Fekete et al. 2012, Kim et al. 2012, van Uitert et al. 2013). In addition, polymorphisms in the MTHFR gene are suggested to contribute to the risk of developing psychiatric disorders, including depression, schizophrenia, and bipolar disorder (Gilbody et al. 2007).

It can be concluded that alterations in the availability of folate during pregnancy may lead to variations in DNA methylation patterns in the offspring, which sometimes also change gene expression and outcomes of disease (Niculescu \& Zeisel 2002, Waterland et al. 2006, Sinclair et al. 2007). Against this background, we investigated the determinants of maternal 1-C metabolism in early pregnancy, i.e. folate and homocysteine concentrations, polymorphisms of the folate metabolizing gene MTHFR C677T (rs1801133), and folic acid supplement use in association with the newborn epigenome.

We related these factors to the overall DNA methylation status of seven genes that were selected based on literature. Variations in these genes are assumed to influence neuronal development (glucocorticoid receptor (NR3C1), presynaptic genes (dopamine receptor D4 (DRD4) and serotonin transporter protein (5-HTT)) or fetal growth (IGF2DMR, H19, and potassium channel protein (KCNQ1OT1)), and 1-C metabolism, i.e. MTHFR.

\section{Materials and methods}

\section{Design and study population}

This study was embedded in the Generation R Study, an ongoing population-based birth cohort followed from fetal life onwards in Rotterdam, The Netherlands. The Generation R Study, designed to identify early environmental and genetic determinants of growth, development and health, has been previously described in detail (Jaddoe et al. 2012).

The study population comprised a subset $(n=540)$ of mother-child pairs of the original Generation R cohort. To reduce the effect of population stratification, we first restricted the study population to the newborns of Dutch national origin based on the country of birth of the parents and grandparents. Next, we selected newborns with a sufficient quantity and quality of DNA derived from umbilical cord blood white blood cells. Finally, we oversampled newborns diagnosed with attention-deficit hyperactive disorder (ADHD; $n=92$ ) in childhood and those born small for gestational age (SGA, $n=100$ ), because of previous study questions (Bouwland-Both et al. 2013, van Mil et al. 2014), and 348 newborns were randomly selected from the original cohort. We carried out the analyses with and without the oversampled ADHD and SGA newborns.

The current study assessed multiple determinants of the 1-C metabolism (i.e. maternal and cord blood folate and homocysteine concentrations, maternal folic acid supplement use, and maternal and newborn MTHFR C677T genotype) in relation to the outcome. To avoid the loss of power and bias due to complete case selection, we performed the analyses in samples of varying size: of the 540 mother-child pairs $413(76 \%)$ had data on maternal early pregnancy (median 13.0 weeks of gestation, $90 \%$ range 10.4-17.1) plasma folate, and homocysteine concentrations. Plasma folate and homocysteine concentrations of the newborn were measured in $420(77 \%)$ mother-child pairs.

Information on maternal folic acid supplement use was present for $440(81 \%)$ of the 540 mother-child pairs. Maternal MTHFR C677T genotype was available in 463 (86\%) motherchild pairs and information about the newborn MTHFR C677T genotype in 473 mother-child pairs (88\%). The study has been approved by the Medical Ethics Committee of the Erasmus MC, University Medical Centre, Rotterdam, The Netherlands.

\section{Assessment of biomarkers of 1-C metabolism}

In early pregnancy (median gestational age 13.0 weeks, $90 \%$ range 10.4-17.1), venous blood samples were drawn in plain tubes for the determination of plasma folate and homocysteine. The samples were transported to the regional laboratory for storage at $-80^{\circ} \mathrm{C}$ within $3 \mathrm{~h}$ after sampling. Ethylenediaminetetraacetic acid plasma samples were picked and analyzed using an immunoelectrochemoluminescence assay on the Architect System (Abbott Diagnostics B.V.). The between-run coefficients of variation (CV) for plasma folate were $8.9 \%$ at $5.6 \mathrm{nmol} / \mathrm{l}, 2.5 \%$ at $16.6 \mathrm{nmol} / \mathrm{l}$, and $1.5 \%$ at $33.6 \mathrm{nmol} / \mathrm{l}$, with an analytical range of $1.8-45.3 \mathrm{nmol} / \mathrm{l}$. The same CV for plasma homocysteine were $3.1 \%$ at $7.2 \mu \mathrm{mol} / \mathrm{l}, 3.1 \%$ at $12.9 \mu \mathrm{mol} / \mathrm{l}$, and $2.1 \%$ at $26.1 \mu \mathrm{mol} / \mathrm{l}$, with an analytic range of 1-50 $\mu \mathrm{mol} / \mathrm{l}$ (Bergen et al. 2012).

\section{Maternal folic acid supplement use}

In early pregnancy, at the same moment of blood sampling, self-administered questionnaires were filled in by the mothers to obtain information on the use and initiation of folic acid and multivitamin supplements. In The Netherlands, a daily supplement of $0.4-0.5 \mathrm{mg}$ folic acid is advised to the general population of women planning pregnancy up to 10 weeks of gestation (Weggemans et al. 2009). The mothers were categorized according to the moment of initiation of periconception folic acid supplement use as follows: i) preconception initiation, ii) initiation after conception but before 10 weeks of gestation, or iii) no use. This categorization has been applied to previous publications from the same study cohort (Roza et al. 2010).

\section{MTHFR genotyping}

To assess the genotypes, DNA was extracted from white blood cells obtained from mothers in early pregnancy and newborns 
at birth. Genotyping of the MTHFR C677T polymorphism (rs1801133) was performed by using TaqMan allelic discrimination assay (Applied Biosystems, Foster City, CA) and Abgene QPCR ROX mix (Abgene, Hamburg, Germany). The genotyping reaction was amplified by using the GeneAmp PCR system 9700 $\left(95^{\circ} \mathrm{C}\right.$ for $\left.15 \mathrm{~min}\right)$, then 40 cycles of $94^{\circ} \mathrm{C}(15 \mathrm{~s})$ and $60{ }^{\circ} \mathrm{C}$ (1 min). The fluorescence was detected on the $7900 \mathrm{HT}$ Fast Real-Time PCR System (Applied Biosystems), and individual genotypes were determined by using SDS Software (version 2.3; Applied Biosystems). The frequency distributions agreed with the Hardy-Weinberg equilibrium (Supplementary Table 2, see section on supplementary data given at the end of this article).

\section{Measurements of DNA methylation}

Based on literature, we selected genes implicated in fetal growth and neuronal development 5-HTT, DRD4, IGF2DMR, H19, KCNQ1OT1, NR3C1, CCNL1/LEKR1 and 1-C metabolism, i.e. MTHFR (Supplementary Table 1, see section on supplementary data given at the end of this article). Hence, we chose to investigate the CpG islands of the genes. We selected the middle region or outer regions per $\mathrm{CpG}$ island or the region previously investigated by other groups.

Two regions of the 5-HTT gene were selected based on publication by Philibert et al. (2008), in which the relationship with depression and alcohol dependency has been investigated.

Previously, Wong et al. (2010) described epigenetic differences in twins in the region of the DRD4 gene and one of the regions in the 5-HTT gene. Epigenetic regulation of the NR3C1 gene has been associated with childhood abuse (McGowan et al. 2009). We selected the same regions of the IGF2DMR and H19 gene as previously reported by Talens et al. (2010), which are implicated in fetal growth. The primers of the other regions in the KCNQ1OT1, MTHFR, and NR3C1 genes were designed using the online tool of EpiDesigner (www. epidesigner.com).

The isolated genomic DNA (500 ng) from cord blood samples was treated with sodium bisulfite for $16 \mathrm{~h}$ using the EZ-96 DNA Methylation Kit (Shallow; Zymo Research, Irvine, CA, USA). This was followed by PCR amplification, fragmentation after RT, and analysis on a mass spectrometer (Sequenom, Inc., San Diego, CA, USA). This generated mass spectra that were translated into quantitative DNA methylation levels of different CpG sites by MassARRAY EpiTYPER Analyzer Software (v1.0, build 1.0.6.88; Sequenom, Inc.).

The samples were randomly divided over bisulfite conversion batches. For each individual, the assays were amplified from the same bisulfite-treated DNA. All methylation measurements were performed in triplicate from the same bisulfitetreated DNA. Fragments containing one or more CpG sites were called $\mathrm{CpG}$ units. The following procedure has been followed for the quality control of the methylation data: i) exclusion of $\mathrm{CpG}$ units with too low or too high mass or $\mathrm{CpG}$ units with overlapping or duplicate RNA fragments (e.g. silent signals), ii) for inclusion of CpG units at least two out of three replicate measurements per $\mathrm{CpG}$ unit had to be successful, iii) for inclusion of CpG units the s.D. of the triplicates (or duplicates) had to be $\leq 0.10$ and the success rate per CpG unit had to be $\geq 75 \%$, and iv) exclusion of CpG units with the interference of single-nucleotide polymorphisms (CEU) (SNPS) with a frequency $>5 \%$ as this could interfere with the measurement by a change of weight of the CpG unit. Because the assessment of the selected region near the gene CCNL1/LEKR1 was unsuccessful due to measurement errors, this data were not analyzed any further.

\section{Covariates}

The following possible confounders were based on expertise and literature review (Steegers-Theunissen et al. 2009, Obermann-Borst et al. 2011, McKay et al. 2012).

Information on maternal education, prenatal smoking, and alcohol consumption was obtained by questionnaires during early pregnancy. The educational level of the mother was assessed by the highest completed education and reclassified into three categories: primary school only, secondary school, and higher education. Maternal prenatal was classified as 'non-smoking', 'smoking until pregnancy was confirmed', and 'continued smoking during pregnancy'. Data on newborn gender, birth weight, and gestational age at birth were derived from medical records completed by midwives and gynecologists. Birth weight was expressed as gestational age and genderadjusted SDSs (Verburg et al. 2008).

\section{Statistical analysis}

First, we examined the association between a derangement in maternal 1-C metabolism, reflected by a low plasma folate or high homocysteine, and newborn DNA methylation of all genes combined. Therefore, we tested for a threshold effect of folate deficiency defined as a plasma concentration of $<7 \mathrm{nmol} / \mathrm{l}$ (percentile 6.4; Simpson et al. 2010). In a similar way, we tested for associations between maternal plasma homocysteine concentration of $>11 \mu \mathrm{mol} / \mathrm{l}$ (percentile 95.2) and child DNA methylation levels (Hague 2003).

Next, we used plasma folate and homocysteine as a continuous variable in the equation. To understand the effect of potential confounders on DNA methylation we used a crude and an adjusted model with gestational age at the moment of blood sampling, maternal smoking, and gestational age at birth as covariates. The covariates were selected and included in the models if they changed the effect estimates of the main association (maternal folate concentration and newborn DNA methylation level) $>10 \%$ (Walter \& Tiemeier 2009). Maternal alcohol consumption was not included in models because this did not materially change the effect estimates.

In addition, we tested for an association between folic acid supplement use and newborn DNA methylation, with mothers who initiated the use of folic acid supplements preconceptionally as the reference category.

Finally, we used the maternal MTHFR rs1801133 genotype as a proxy for baseline folate status to study the association between folate status and child DNA methylation. Based on studies investigating folate and homocysteine concentrations in individuals heterozygous and homozygous for the 677T allele (Frosst et al. 1995, Jacques et al. 2002), we used a recessive model using both the CC and CT genotypes as reference with 
the TT alleles as risk genotype. To check whether the genetic effects were specific for the mother, we additionally tested for an association between child MTHFR genotype and DNA methylation.

As SNPs have previously been found to be correlated with local DNA methylation patterns, mostly within a distance of $149 \mathrm{~kb}$ of CpG dinucleotides (Zhang et al. 2010, Bell et al. 2011), we also tested the associations after excluding the MTHFR region in the analysis. In addition, to test whether results were dependent on the sampling strategy with an oversampling of newborns with childhood ADHD or those born SGA, all analyses were repeated excluding these samples.

For an initial overall analysis of methylation and ADHD symptom score, DNA methylation levels of all CpG units in the 11 regions together were combined in one analysis. We present the complete data from all regions selected and chose a hierarchical approach to reduce the risk of type 1 error rather than to report selectively. Next to specific effects of DNA methylation, general effects on the level of DNA methylation have been described. Besides, the specific regions are correlated; a combined analysis increases the power and helps to detect small effects of DNA methylation. Consequently, we have to be very careful to interpret specific effects on DNA methylation as the focus was on the overall effect.

DNA methylation levels were treated as continuous variables. To approximate normal distribution, variables of DNA methylation levels were transformed by the square-root. In the analyses, the triplicate measurements and DNA methylation levels of the separate CpG sites within a region were treated as clustered variables in a restructured data file and not as a mean.

As CpG sites within one region might be correlated, the associations with DNA methylation level were calculated using linear mixed models. Mixed models have the advantage to allow correlated random effects in individuals. Another advantage of this model is the ability to accommodate missing data points. Furthermore, using mixed models enables adjustment for relevant covariates on the raw data in the same model (Burton et al. 1998).

To further illustrate the effect of maternal MTHFR C677T genotype, we tested the association between the different maternal alleles and newborn cord blood concentrations of folate and homocysteine using ANOVA. In addition, we tested the association between maternal periconceptional folic acid supplement use and maternal early pregnancy plasma folate and homocysteine concentrations.

Finally, to test whether our sampling strategy influenced our results, we carried out the analyses with and without the oversampled ADHD and SGA newborns. All analyses were performed using SPSS Software (version 20.0; IBM-SPSS).

\section{Results}

The characteristics of the newborns and their mothers in the study population are presented in Table 1 . Mothers had a mean age of 30.1 years (s.D. 4.8), 29.5\% was higher educated and $32.9 \%$ smoked during pregnancy. The children were born after a mean of 40.1 weeks of gestation (s.D. 1.5), 71.8\% was born after spontaneous
Table 1 Characteristics of the mothers and their newborns.

\begin{tabular}{ll}
\hline Newborn & $n=420$ \\
Gender, boys (\%) & 60.2 \\
Birth weight (g) & $3404(582)$ \\
Mother & $30.1(4.8)$ \\
Age (years) & 66.3 \\
Parity, nulliparous (\%) & $13.0(10.4-17.1)$ \\
Gestational age at study entry (weeks), & \\
median (90\% range) & $40.1(1.5)$ \\
Gestational age at delivery (weeks) & $24.1(4.0)$ \\
BMI (kg/m ${ }^{2}$ ) & 19.8 \\
Educational level (\%) & 50.7 \\
Primary & 29.5 \\
Secondary & 67.1 \\
High & 9.8 \\
Smoking during pregnancy (\%) & 23.1 \\
Never & \\
Until pregnancy confirmation & 55.9 \\
Continued & 31.4 \\
Periconceptional folic acid supplement use (\%) & 12.7 \\
Start preconceptionally & $19.1(9.0)$ \\
Start within first 10 weeks of gestation & \\
No use & $7.0(4.9-10.9)$ \\
Plasma folate concentrations in early & \\
pregnancy (nmol/l) & \\
Plasma homocysteine concentrations in & \\
early pregnancy ( $\mu$ mol/l), median & \\
(90\% range) & \\
Mode of delivery (\%) & \\
Spontaneous vaginal & \\
Instrumental vaginal & 6.5 \\
Caesarean section & \\
\hline
\end{tabular}

Values represent means (s.D.) unless otherwise indicated.

vaginal delivery and the mean birth weight was $3404 \mathrm{~g}$ (s.D. 582).

The associations between maternal folate and homocysteine concentrations in early pregnancy and overall DNA methylation levels in the 11 regions of seven fetal growth and neuronal developmental genes in the newborn are shown in respectively Tables 2 and 3 . The continuous analysis of the maternal biomarkers showed no significant associations with the DNA methylation levels in newborns. However, early pregnancy exposure to folate deficiency, resulting in a deranged 1-C metabolism, revealed an overall lower DNA methylation level $(\beta-0.39,95 \% \mathrm{Cl}-0.74 ;-0.03, P=0.03)$ that was attenuated after adjustment for potential confounders. The homocysteine concentration was not associated with newborn DNA methylation levels in the overall analyses of all regions measured.

Newborns of mothers who initiated folic acid supplement use in the first 10 weeks of gestation or did not use folic acid supplements did not show different DNA methylation levels compared with newborns of mothers who initiated folic acid supplement use preconceptionally, the reference category (Table 4).

As presented in Table 5, the maternal MTHFR risk genotype (TT) predicted a lower overall DNA methylation level in the newborn $(\beta-0.31,95 \% \mathrm{Cl}-0.59$; $-0.02, P=0.03)$. As SNPs can influence DNA 
Table 2 Associations between maternal early pregnancy plasma folate and newborn DNA methylation levels.

\begin{tabular}{|c|c|c|c|c|}
\hline & \multicolumn{4}{|c|}{ Methylation $\boldsymbol{\beta}(95 \% \mathrm{Cl})$} \\
\hline & \multicolumn{2}{|c|}{ Unadjusted } & \multicolumn{2}{|c|}{ Adjusted } \\
\hline & Continuous $(\mu \mathrm{mol} / \mathrm{l})$ & $\begin{array}{c}\text { Deficient }<7 \mathrm{nmol} / \mathrm{I} \\
\quad(n=27)\end{array}$ & Continuous $(\mu \mathrm{mol} / \mathrm{l})$ & $\begin{array}{c}\text { Deficient }<7 \mathrm{nmol} / \mathrm{I} \\
\quad(n=27)\end{array}$ \\
\hline \multicolumn{5}{|l|}{ Overall } \\
\hline All genes assessed & $-3.98(-13.75 ; 5.80)$ & $-0.39(-0.74 ;-0.03)$ & $-9.08(-20.0 ; 1.85)$ & $-0.01(-0.40 ; 0.38)$ \\
\hline$P$ value & 0.42 & 0.03 & 0.10 & 0.95 \\
\hline \multicolumn{5}{|c|}{ Neurotransmitter systems } \\
\hline DRD4 & $-8.81(-60.27 ; 42.67)$ & $-1.71(-3.57 ; 0.15)$ & $-51.59(-105.37 ; 2.20)$ & $-0.07(-1.99 ; 1.86)$ \\
\hline$P$ value & 0.74 & 0.07 & 0.06 & 0.94 \\
\hline 5-HTT_a & $7.56(-6.87 ; 21.99)$ & $-0.11(-0.64 ; 0.41)$ & $7.99(-7.76 ; 23.75)$ & $-0.17(-0.73 ; 0.39)$ \\
\hline$P$ value & 0.30 & 0.67 & 0.32 & 0.54 \\
\hline 5-HTT_b & $-6.66(-23.08 ; 9.76)$ & $-0.23(-0.85 ; 0.38)$ & $-14.73(-31.37 ; 2.42)$ & $0.12(-0.51 ; 0.74)$ \\
\hline$P$ value & 0.43 & 0.46 & 0.09 & 0.72 \\
\hline 5-HTT_C & $-13.04(-30.00 ; 3.90)$ & $0.03(-0.05 ; 0.10)$ & $-17.82(-35.85 ; 0.20)$ & $-0.05(-0.68 ; 0.59)$ \\
\hline$P$ value & 0.13 & 0.59 & 0.05 & 0.89 \\
\hline \multicolumn{5}{|l|}{ Metabolism } \\
\hline NR3C1_a & $7.33(-1.72 ; 16.37)$ & $-0.51(-0.84 ;-0.19)$ & $8.69(-1.22 ; 18.60)$ & $-0.60(-0.94 ;-0.25)$ \\
\hline$P$ value & 0.11 & 0.002 & 0.09 & 0.001 \\
\hline NR3C1_b & $4.74(-6.84 ; 16.32)$ & $-0.36(-0.77 ; 0.06)$ & $3.53(-9.10 ; 16.16)$ & $-0.21(-0.65 ; 0.24)$ \\
\hline$P$ value & 0.42 & 0.09 & 0.58 & 0.37 \\
\hline NR3C1_C & $2.73(-7.95 ; 13.41)$ & $-0.05(-0.43 ; 0.34)$ & $3.69(-7.95 ; 15.34)$ & $-0.03(-0.44 ; 0.38)$ \\
\hline$P$ value & 0.62 & 0.81 & 0.53 & 0.89 \\
\hline MTHFR5 & $-1.35(-9.84 ; 7.14)$ & $0.02(-0.29 ; 0.32)$ & $-4.07(-13.23 ; 5.09)$ & $0.09(-0.24 ; 0.42)$ \\
\hline$P$ value & 0.76 & 0.91 & 0.38 & 0.59 \\
\hline \multicolumn{5}{|l|}{ Fetal growth } \\
\hline $\mathrm{H} 19$ & $-18.32(-44.38 ; 7.74)$ & $-23.08(-1.18 ; 7.17)$ & $15.70(-44.25 ; 12.84)$ & $-0.27(-1.29 ; 7.47)$ \\
\hline$P$ value & 0.17 & 0.63 & 0.28 & 0.60 \\
\hline$I G F 2 D M R$ & $7.72(-28.15 ; 43.59)$ & $-1.08(-2.39 ; 0.24)$ & $3.32(-35.32 ; 41.95)$ & $-0.74(-2.13 ; 0.65)$ \\
\hline$P$ value & 0.67 & 0.11 & 0.87 & 0.30 \\
\hline KCNQ1OT1 & $-23.74(-53.56 ; 6.07)$ & $-0.24(-1.33 ; 0.85)$ & $-21.90(-54.45 ; 10.65)$ & $-0.41(-1.58 ; 0.75)$ \\
\hline$P$ value & 0.12 & 0.66 & 0.19 & 0.48 \\
\hline
\end{tabular}

The $\beta$ represents the change in methylation $\% / 1 \mu \mathrm{mol}$ per I increase in folate concentration (continuous) or the change in methylation $\%$ in folate deficiency $(<7 \mu \mathrm{mol} / \mathrm{l})$ compared with adequate concentrations $\geq 7 \mu \mathrm{mol} / \mathrm{l}$ as analyzed with linear mixed models. Values represent $\beta, 95 \% \mathrm{Cls}$, and $P$ values. Analyses are adjusted for gestational age at the moment of blood sampling, maternal educational level, smoking, child gender, birth weight, and gestational age at birth. The bold values indicate statistical significance at the $\alpha=0.05$ level.

methylation in the adjacent region, we checked whether this association was dependent on methylation levels in the measured MTHFR region. The association between the maternal MTHFR C677T genotype and DNA methylation level in the newborn was also observed after excluding the MTHFR region from the analyses $(\beta-0.37,95 \% \mathrm{Cl}-0.68 ;-0.04, P=0.02)$. There was no significant association between the newborn MTHFR C677T genotype and overall DNA methylation.

We were not able to investigate whether the effect of the folate concentration was modified by the maternal MTHFR C677T genotype due to the small number of newborns $(n=4)$ exposed to folate deficiency in mothers carrying the MTHFR TT genotype.

Maternal MTHFR C677T genotype was not associated with alterations in newborns' cord blood folate or homocysteine levels (Supplementary Table 3, see section on supplementary data given at the end of this article). The plasma folate concentrations measured in early pregnancy were highest in women starting folic acid supplement use preconceptionally (mean $21.92 \mathrm{nmol} / \mathrm{l}$, $95 \% \mathrm{Cl} 20.76$; 23.01) compared with women starting folic acid supplement use in the first 10 weeks of gestation $(18.33 \mathrm{nmol} / \mathrm{l}, 95 \% \mathrm{Cl} 16.81 ; 19.86, P \leq 0.001)$ or women not using folic acid supplements (mean $8.59 \mathrm{nmol} / \mathrm{l}, 95 \% \mathrm{Cl} 6.24 ; 10.93, P<0.001)$. Early pregnancy homocysteine concentrations were lower in women using folic acid supplements preconceptionally (mean $7.11 \mu \mathrm{mol} / \mathrm{l}, 95 \% \mathrm{Cl} 6.80 ; 7.43$ ) as compared with women starting folic acid supplements in the first 10 weeks of gestation (mean $7.46 \mu \mathrm{mol} / \mathrm{l}, 95 \% \mathrm{Cl} 7.05$; $7.88, P=0.19)$ or women not using folic acid supplements (mean $9.37 \mu \mathrm{mol} / \mathrm{l}, 90 \%$ range $8.87 ; 10.02$, $P<0.001$ ) (Supplementary Table 4, see section on supplementary data given at the end of this article).

When analyses were repeated with exclusion of newborns SGA or with ADHD, the results did not change materially (results not shown).

\section{Discussion}

\section{Main findings}

There is a substantial interest in the impact of derangements in periconception maternal 1-C metabolism on newborn DNA methylation profiles with implications for birth outcome and health 
Table 3 Associations between maternal pregnancy plasma homocysteine and newborn DNA methylation levels.

\begin{tabular}{|c|c|c|c|c|}
\hline & \multicolumn{4}{|c|}{ Methylation $\boldsymbol{\beta}(95 \% \mathrm{Cl})$} \\
\hline & \multicolumn{2}{|c|}{ Unadjusted } & \multicolumn{2}{|c|}{ Adjusted } \\
\hline & Continuous $(\mu \mathrm{mol} / \mathrm{l})$ & $\begin{array}{l}\text { Elevated homocysteine } \\
>11 \mu \mathrm{mol} / \mathrm{l}(n=30)\end{array}$ & Continuous $(\mu \mathrm{mol} / \mathrm{l})$ & $\begin{array}{c}\text { Elevated homocysteine } \\
>11 \mu \mathrm{mol} / \mathrm{l}(n=30)\end{array}$ \\
\hline \multicolumn{5}{|l|}{ Overall } \\
\hline All genes assessed & $-0.01(-0.05 ; 0.02)$ & $-0.05(-0.39 ; 0.29)$ & $0.00(-0.03 ; 0.04)$ & $0.06(-0.27 ; 0.39)$ \\
\hline$P$ value & 0.48 & 0.76 & 0.87 & 0.73 \\
\hline \multicolumn{5}{|c|}{ Neurotransmitter systems } \\
\hline DRD4 & $-0.06(-0.26 ; 0.14)$ & $-0.45(-2.22 ; 1.33)$ & $0.03(-0.17 ; 0.23)$ & $0.26(-1.51 ; 2.03)$ \\
\hline$P$ value & 0.53 & 0.62 & 0.74 & 0.77 \\
\hline 5-HTT_a & $0.03(-0.03 ; 0.09)$ & $-0.03(-0.52 ; 0.47)$ & $0.02(-0.04 ; 0.08)$ & $-0.04(-0.55 ; 0.47)$ \\
\hline$P$ value & 0.29 & 0.91 & 0.46 & 0.87 \\
\hline 5-HTT_b & $0.00(-0.06 ; 0.07)$ & $-0.10(-0.67 ; 0.47)$ & $0.03(-0.04 ; 0.09)$ & $0.09(-0.47 ; 0.64)$ \\
\hline$P$ value & 0.89 & 0.73 & 0.40 & 0.76 \\
\hline 5-HTT_C & $-0.05(-0.11 ; 0.02)$ & $-0.37(-0.96 ; 0.23)$ & $-0.04(-0.11 ; 0.03)$ & $-0.28(-0.88 ; 0.31)$ \\
\hline$P$ value & 0.16 & 0.23 & 0.24 & 0.35 \\
\hline \multicolumn{5}{|l|}{ Metabolism } \\
\hline NR3C1_a & $-0.04(-0.08 ;-0.01)$ & $-0.27(-0.58 ; 0.04)$ & $-0.04(-0.08 ;-0.04)$ & $-0.26(-0.58 ; 0.06)$ \\
\hline$P$ value & 0.02 & 0.09 & 0.03 & 0.11 \\
\hline$N R 3 C 1 \_b$ & $-0.04(-0.08 ; 0.01)$ & $-0.38(-0.78 ; 0.02)$ & $-0.03(-0.08 ; 0.02)$ & $-0.39(-0.80 ; 0.02)$ \\
\hline$P$ value & 0.11 & 0.06 & 0.20 & 0.07 \\
\hline NR3C1_c & $-0.02(-0.06 ; 0.02)$ & $-0.29(-0.66 ; 0.09)$ & $-0.02(-0.06 ; 0.03)$ & $-0.33(-0.71 ; 0.06)$ \\
\hline$P$ value & 0.40 & 0.13 & 0.45 & 0.10 \\
\hline MTHFR5 & $-0.03(-0.07 ; 0.00)$ & $-0.16(-0.46 ; 0.13)$ & $-0.03(-0.07 ; 0.00)$ & $-0.11(-0.41 ; 0.19)$ \\
\hline$P$ value & 0.04 & 0.27 & 0.07 & 0.48 \\
\hline \multicolumn{5}{|l|}{ Fetal growth } \\
\hline$H 19$ & $0.09(-0.01 ; 0.19)$ & $1.00(0.10 ; 1.90)$ & $0.09(-0.01 ; 0.20)$ & $0.92(-0.01 ; 1.86)$ \\
\hline$P$ value & 0.07 & 0.03 & 0.09 & 0.05 \\
\hline IGF2DMR & $-0.06(-0.21 ; 0.08)$ & $-0.29(-1.55 ; 0.96)$ & $-0.08(-0.23 ; 0.07)$ & $-0.32(-1.60 ; 0.96)$ \\
\hline$P$ value & 0.41 & 0.65 & 0.30 & 0.62 \\
\hline KCNQ1OT1 & $0.06(-0.06 ; 0.18)$ & $0.10(-0.95 ; 1.15)$ & $0.05(-0.07 ; 0.18)$ & $0.05(-1.03 ; 1.14)$ \\
\hline$P$ value & 0.33 & 0.85 & 0.40 & 0.92 \\
\hline
\end{tabular}

The $\beta$ represents the change in methylation $\% / 1 \mu \mathrm{mol}$ per I increase in homocysteine concentration (continuous) or the change in methylation $\%$ in elevated homocysteine concentration $(>11 \mu \mathrm{mol} / \mathrm{l})$ compared with adequate concentrations $\leq 11 \mu \mathrm{mol} / \mathrm{l}$ as analyzed with linear mixed models. Values represent $\beta, 95 \% \mathrm{Cls}$, and $P$ values. Analyses are adjusted for gestational age at the moment of blood sampling, maternal educational level, smoking, child gender, birth weight, and gestational age at birth. The bold values indicate statistical significance at the $\alpha=0.05$ level.

(Steegers-Theunissen et al. 2013). In this study, we observed a significant association between the maternal MTHFR 677TT genotype and newborn overall DNA methylation levels of fetal growth and neuronal developmental genes. The association between maternal folate deficiency measured in early pregnancy and newborn DNA methylation was attenuated after correction for maternal educational level, smoking, child gender, birth weight, and gestational age at birth.

\section{Strengths and limitations}

Some strengths and limitations have to be addressed. This study was embedded in a large cohort, from which a selection of Dutch newborns was studied. Detailed information on maternal folate and homocysteine concentrations, folic acid supplement use, and MTHFR C677T genotype in mothers and newborns was prospectively collected. Furthermore, to correct for possible confounding factors, including information on maternal educational level, smoking and child birth weight have been carefully documented.

A first limitation is the unsolved question how alterations in DNA methylation profiles in umbilical cord blood white blood cells reflect DNA methylation profiles in other tissues. This is a problem in most human studies. Ghosh et al. (2010) analyzed DNA methylation variation across brain and blood and found that, although between-tissue variation exceeds betweenindividual variation, inter-individual variation was reflected across brain and blood. This implies that peripheral tissues may be of use for epidemiological studies. Talens et al. (2010) reported for four of eight investigated regions, including IGF2DMR and H19 used in the current study, strong correlations between DNA methylation profiles in blood and buccal cells, tissues from different germ layers. Recently, we described tissue specificity of IGF2DMR and $\mathrm{H} 19$ gene regions among four umbilical cord blood tissues and concluded that the mononuclear cell fraction of umbilical cord blood is a rather homogeneous cell population for methylation studies (Herzog et al. 2013). However, no studies have compared the agreement between umbilical cord blood white blood cells and peripheral tissues as yet.

Second, folate and homocysteine concentrations were determined in blood samples obtained in early pregnancy at the same time when information on maternal folic acid supplement use was collected. A limitation of 
Table 4 Associations between maternal periconceptional folic acid supplement use and newborn DNA methylation levels.

\begin{tabular}{|c|c|c|c|c|}
\hline & \multicolumn{4}{|c|}{ Methylation $\boldsymbol{\beta}(95 \% \mathrm{Cl})$} \\
\hline & \multicolumn{2}{|c|}{ Unadjusted } & \multicolumn{2}{|c|}{ Adjusted } \\
\hline & Start within 10 weeks & No use & Start within 10 weeks & No use \\
\hline \multicolumn{5}{|l|}{ Overall } \\
\hline All genes assessed & $0.08(-0.11 ; 0.27)$ & $-0.14(-0.39 ; 0.11)$ & $0.07(-0.16 ; 0.31)$ & $0.20(-0.15 ; 0.54)$ \\
\hline$P$ value & 0.42 & 0.27 & 0.56 & 0.26 \\
\hline \multicolumn{5}{|c|}{ Neurotransmitter systems } \\
\hline DRD4 & $0.35(-0.64 ; 1.35)$ & $-5.56(-1.87 ; 0.74)$ & $0.94(-0.06 ; 1.94)$ & $0.67(-0.72 ; 2.06)$ \\
\hline$P$ value & 0.49 & 0.40 & 0.07 & 0.34 \\
\hline 5-HTT_a & $-0.14(-0.20 ; 0.37)$ & $-0.14(-0.51 ; 0.23)$ & $0.08(-0.21 ; 0.38)$ & $-0.20(-0.61 ; 0.21)$ \\
\hline$P$ value & 0.55 & 0.46 & 0.57 & 0.33 \\
\hline 5-HTT_b & $0.10(-0.22 ; 0.42)$ & $0.28(-0.16 ; 0.71)$ & $0.16(-0.16 ; 0.48)$ & $0.47(0.02 ; 0.92)$ \\
\hline$P$ value & 0.54 & 0.21 & 0.32 & 0.04 \\
\hline 5-HTT_C & $0.07(-0.27 ; 0.40)$ & $0.15(-0.29 ; 0.59)$ & $0.09(-0.24 ; 0.43)$ & $0.17(-0.30 ; 0.64)$ \\
\hline$P$ value & 0.69 & 0.51 & 0.58 & 0.48 \\
\hline \multicolumn{5}{|l|}{ Metabolism } \\
\hline NR3C1_a & $0.05(-0.23 ; 0.12)$ & $-0.16(-0.39 ; 0.07)$ & $0.06(-0.24 ; 0.12)$ & $-0.29(-0.54 ;-0.03)$ \\
\hline$P$ value & 0.56 & 0.17 & 0.52 & 0.03 \\
\hline NR3C1_b & $0.20(-0.04 ; 0.43)$ & $-0.07(-0.37 ; 0.24)$ & $0.18(-0.06 ; 0.43)$ & $0.01(-0.33 ; 0.35)$ \\
\hline$P$ value & 0.11 & 0.67 & 0.15 & 0.96 \\
\hline NR3C1_C & $0.08(-0.13 ; 0.29)$ & $-0.10(-0.38 ; 0.18)$ & $0.09(-0.13 ; 0.31)$ & $-0.11(-0.42 ; 0.20)$ \\
\hline$P$ value & 0.46 & 0.47 & 0.43 & 0.48 \\
\hline MTHFR5 & $-0.01(-0.18 ; 0.16)$ & $0.13(-0.09 ; 0.35)$ & $0.02(-0.16 ; 0.19)$ & $0.13(-0.11 ; 0.38)$ \\
\hline$P$ value & 0.91 & 0.25 & 0.87 & 0.29 \\
\hline \multicolumn{5}{|l|}{ Fetal growth } \\
\hline $\mathrm{H} 19$ & $0.42(-0.09 ; 0.93)$ & $-0.16(-0.39 ; 0.07)$ & $0.44(-0.09 ; 0.97)$ & $0.41(-0.32 ; 1.14)$ \\
\hline$P$ value & 0.10 & 0.39 & 0.10 & 0.27 \\
\hline IGF2DMR & $-0.03(-0.73 ; 0.67)$ & $-0.87(-1.79 ; 0.04)$ & $0.23(-0.49 ; 0.94)$ & $-0.41(-1.40 ; 0.59)$ \\
\hline$P$ value & 0.94 & 0.06 & 0.53 & 0.42 \\
\hline KCNQ1OT1 & $0.48(-11.48 ; 1.08)$ & $0.12(-0.67 ; 0.91)$ & $0.56(-0.06 ; 1.19)$ & $0.03(-0.84 ; 0.90)$ \\
\hline$P$ value & 0.11 & 0.76 & 0.08 & 0.95 \\
\hline
\end{tabular}

A start preconceptionally was regarded as reference value. The $\beta$ represents the change in methylation \% in start within 10 weeks of pregnancy or no use during pregnancy as analyzed with linear mixed models. Values represent $\beta, 95 \% \mathrm{Cls}$, and $P$ values. Analyses are adjusted for gestational age at the moment of blood sampling, maternal educational level, smoking, child gender, birth weight, and gestational age at birth. The bold values indicate statistical significance at the $\alpha=0.05$ level.

the study is the absence of information on the duration of maternal folic acid use and repeated measurements of these concentrations during gestation. Although it is not known how DNA methylation of the fetus and placenta develop throughout pregnancy, the epigenetic system is thought to be primarily sensitive to environmental factors during the period of developmental plasticity (Barouki et al. 2012).

Third, in the current study we describe several associations between determinants of maternal 1-C metabolism and alterations in newborn DNA methylation profiles. However, it is difficult to describe the potential influence of these effects on health outcomes. It is difficult to translate our findings on newborn DNA methylation to health outcomes, as literature describing the effects of alterations in DNA methylation is limited. Unfortunately, in the current study we were unable to relate our findings to gene expression data. Therefore, it would be valuable to replicate our findings and to validate DNA methylationmarkers.

Fourth, for an initial overall analysis of determinants of the maternal 1-C metabolism and newborn DNA methylation, methylation levels of all CpG units in the 11 regions together were combined in one analysis. We present the complete data from all regions selected and chose a hierarchical approach to reduce the risk of type 1 error rather than to report selectively. Next to specific effects of DNA methylation, general effects on the level of DNA methylation have been described. Besides, the specific regions are correlated, a combined analysis increases the power and helps to detect small effects of DNA methylation. Consequently, we have to be very careful to interpret specific effects on DNA methylation as the focus was on the overall effect.

Finally, our study relied on genomic DNA extracted from white blood cells, which consists of many distinct populations in varying proportions. Therefore, cell heterogeneity may act as a potential confounder when investigating DNA methylation differences, if cell distribution itself differs by one of investigated determinants of the 1-C metabolism. Glossop et al. (2013) demonstrated that DNA methylation varied dramatically between matched-pairs T- and B-lymphocytes in a population of healthy volunteers. On the other hand, cellular heterogeneity is considered to have limited impact when the outcome and the genes are not involved in inflammation (Talens et al. 2010). Reinius et al. (2012) evaluated genome wide DNA methylation of $\sim 450000 \mathrm{CpG}$ sites in different peripheral blood mononuclear cells of six healthy adult male 
Table 5 Associations between the MTHFR C677T (rs1801133) genotype in mothers and newborns and newborn DNA methylation status.

\begin{tabular}{|c|c|c|c|}
\hline & \multicolumn{2}{|c|}{ Methylation $\boldsymbol{\beta}(95 \% \mathrm{Cl})$} & \multirow[b]{2}{*}{ Reference } \\
\hline & Maternal genotype $T T(n=50)$ & Child genotype $T T(n=50)$ & \\
\hline Overall & & & $C C(n=210) / C T(n=203)$ \\
\hline All genes assessed & $-0.31(-0.59 ;-0.02)$ & $0.01(-0.20 ; 0.35)$ & \\
\hline$P$ value & 0.03 & 0.57 & \\
\hline Neurotransmitter systems & & & $C C(n=210) / C T(n=203)$ \\
\hline$D R D 4$ & $-1.56(-3.00 ;-0.08)$ & $-0.03(-1.43 ; 1.37)$ & \\
\hline$P$ value & 0.04 & 0.97 & \\
\hline 5-HTT_a & $-0.22(-0.65 ; 0.21)$ & $0.03(-0.44 ; 0.38)$ & \\
\hline$P$ value & 0.32 & 0.89 & \\
\hline 5-HTT_b & $0.22(-0.21 ; 0.66)$ & $0.10(0.37 ; 0.57)$ & \\
\hline$P$ value & 0.31 & 0.67 & \\
\hline 5-HTT_C & $0.01(-0.48 ; 0.50)$ & $-0.15(0.63 ; 0.33)$ & \\
\hline$P$ value & 0.97 & 0.54 & \\
\hline Metabolism & & & $C C(n=210) / C T(n=203)$ \\
\hline NR3C1_a & $0.10(-0.16 ; 0.38)$ & $0.25(-0.02 ; 0.51)$ & \\
\hline$P$ value & 0.45 & 0.07 & \\
\hline$N R 3 C 1 \_b$ & $0.08(-0.28 ; 0.44)$ & $-0.01(-0.36 ; 0.34)$ & \\
\hline$P$ value & 0.67 & 0.97 & \\
\hline NR3C1_c & $-0.16(-0.48 ; 0.16)$ & $0.06(-0.24 ; 0.37)$ & \\
\hline$P$ value & 0.34 & 0.69 & \\
\hline MTHFR5 & $0.12(-0.15 ; 0.38)$ & $0.15(-0.45 ; 0.75)$ & \\
\hline$P$ value & 0.38 & 0.62 & \\
\hline Fetal growth & & & $C C(n=210) / C T(n=203)$ \\
\hline$H 19$ & $-0.01(-0.80 ; 0.78)$ & $-0.47(-1.20 ; 0.26)$ & \\
\hline$P$ value & 0.98 & 0.21 & \\
\hline IGF2DMR & $-0.55(-1.62 ; 0.52)$ & $0.50(-0.53 ; 1.52)$ & \\
\hline$P$ value & 0.31 & 0.34 & \\
\hline KCNQ1OT1 & $-0.89(-1.80 ; 0.02)$ & $0.04(-0.81 ; 0.89)$ & \\
\hline$P$ value & 0.05 & 0.92 & \\
\hline
\end{tabular}

The $\beta$ represents the change in methylation \% in individuals with the MTHFR 677TT genotype compared with MTHFR 677CT or CC genotype as analyzed with linear mixed models. Values represent $\beta, 95 \% \mathrm{Cls}$, and $P$ values. Analyses are adjusted for newborn birth weight. The bold values indicate statistical significance at the $\alpha=0.05$ level.

donors. In selected genes implicated in immune-related disorders, CpG methylation differed between mononuclear cells and granulocytes and B-cells showing the most distinct profile. Nevertheless, in future studies it could be of added value when performing DNA methylation analyses using whole blood, to adjust the DNA methylation levels for differential cell counts or preferably to evaluate cell-specific patterns for the locus of interest.

\section{Interpretation}

The association between maternal folate deficiency and lower DNA methylation in newborns attenuated after adjustment for maternal educational level, child gender, birth weight, and gestational age at birth. It seems likely that these determinants influence the newborn epigenome also via the maternal 1-C metabolism (Steegers-Theunissen et al. 2013). This is supported by the observed gene-specific effects of gestational age on newborn umbilical cord white blood cell DNA and the reported relationship between maternal smoking and lower methylation levels in the child (Joubert et al. 2012).

Our data support the hypothesis that environmental factors influence the epigenome, which can alter the programing of gene expression and thus potentially contributes to health and disease in later life (Waterland \& Michels 2007). However, causality is difficult to establish in observational studies and therefore confounding or presence of an epiphenomenon cannot be excluded. Information on the factors which might influence the fidelity of DNA methylation profiles is limited. The association between maternal folate status and DNA methylation in newborns could be subject to confounding. This is illustrated by the attenuation of the association after adjustment for confounders. On the other hand, this is also a strength of our study, because in most studies the control for socio-economic factors and maternal smoking is lacking (Cortessis et al. 2012).

Folate is an important provider of methyl groups to 1-C metabolism and hence a major determinant of SAM for the establishment of the human epigenome. Human studies of DNA methylation and folate concentration vary widely in study design, timing and level of exposure, tissue tested, and assays. Our data are supported by the accumulating evidence on the association between a low folate status and global DNA hypomethylation (Crider et al. 2012). Studies of the Dutch hunger winter showed alterations in offspring DNA methylation patterns 60 years after intrauterine exposure to famine, which might be an indicator of a poor folate status (Heijmans et al. 2008, Tobi et al. 2009). In addition, intervention studies in 
postmenopausal women have shown that moderate folate deficiency reduces genome-wide DNA methylation (Jacob et al. 1998, Rampersaud et al. 2000).

Of interest is the finding that both folate deficiency and higher homocysteine concentrations were associated with a decreased newborn DNA methylation level of one of the glucocorticoid receptor gene loci. This locus covers the noncoding exon $1 \mathrm{~F}$ promoter that contains the transcription factor NGFI-A-binding site and is specific to the hippocampus (Turner \& Muller 2005). It is suggested that glucocorticoid receptor expression can be fine-tuned in response to the early life environment. Previous studies investigating DNA methylation in peripheral blood have shown increased levels of NR3C1 methylation in response to neonatal influences (Oberlander et al. 2008, Radtke et al. 2011, Mulligan et al. 2012).

The results of studies addressing folic acid supplement use are sometimes contradicting. We showed that periconception maternal folic acid use significantly increased IGF2DMR methylation in the very young child (Steegers-Theunissen et al. 2009). In mice, low folate supply in utero resulted in gene and locus-specific epigenetic effects in the offspring gut. Lower overall methylation was only in the Slc39a4 CGI1 locus and not in Esr1, Igf2 DMR1, or Slc39a4 CGI2 loci (McKay et al. 2011). However, Haggarty et al. (2013) suggested that preconception folic acid supplement use has no effect on human child DNA methylation. Herein, we did not observe any association between maternal folic acid supplement use and DNA methylation of the combined regions of seven genes in the newborn.

An approach that uses genetic variants as surrogate for measuring exposure has the advantage to provide a relatively unbiased assessment whether modifiable risk factors are causally related to the outcome. Low folate status increases the homocysteine concentration, in particular in individuals with the MTHFR 677TT genotype (Jacques et al. 1996). Consistent with the epigenetic hypothesis, we observed an association between the maternal MTHFR 677TT genotype and lower DNA methylation level in newborns. This may suggest that the maternal genotype is more reliable to reflect the basic folate status than a single measurement of the plasma folate concentration reflecting the folate status of the previous 1-3 days. Unfortunately, we were unable to test interactions or mediation effects due to the small number of mothers and newborns carrying the MTHFR 677CT/TT genotype and with folate deficiency. In the current study, we observed that maternal MTHFR 677TT genotype is related with newborn DNA methylation, but newborn homozygosity for the C677T mutation was not significantly associated with newborn DNA methylation. From studies on associations between folate and neural tube defects, we know that the odds ratio was almost 1.5 times higher if not only the mother but also the fetus carried the TT genotype (van der Put et al. 1996), suggesting that the fetal genotype has an additional effect on the maternal-fetal 1-C metabolism. Other studies have previously reported the fetal ability to concentrate vitamins. Active placental transport resulted in higher levels of folate and vitamin B12 in the fetus than in the mother (Obeid et al. 2005). Probably, because of this mechanism, the fetus is able to maintain a sufficient folate status regardless of its genotype. Furthermore, the maternal 1-C metabolism is essential for DNA methylation reprograming during the early embryonic period (Crider et al. 2012). Probably, this process of demethylation and remethylation takes place shortly after fertilization, a long time before the fetal genotype could exert its effect.

In the current study, we did not observe an association between maternal folic acid supplement use and DNA methylation in the newborn. Possibly the timing of the start of folic acid supplement use could have influenced our findings. DNA methylation reprograming in the early embryo could benefit most from the use of supplements if they are taken before conception (Steegers-Theunissen et al. 2013). Another possibility is that the effects of folic acid supplement use also depend on the MTHFR genotype. Shelnutt et al. (2004) performed a trial in 41 young women with either the MTHFR 677CC or TT genotype. A 7-week folate depletion diet led to lower global DNA methylation in women with either genotype. However, the following 7-week folate repletion diet only led to an increase in global DNA methylation in women with the mutant $T T$ genotype. It is possible that natural folate as part of food exerts different effects on biological processes than synthetic folic acid. It is not elucidated whether the increased uptake of folic acid rather than 5-methyltetrahydrofolate in the 1-C pathway at a critical time can impact on DNA methylation (Smith et al. 2008).

Experimental evidence is suggesting that epigenetic marks serve as a memory of exposure in early life and can increase the vulnerability to develop disease in later life. In this study, changes in DNA methylation level in response to the maternal the MTHFR genotype, although statistically significant, were relatively small. The magnitude of differences in DNA methylation is difficult to interpret and most importantly the thresholds of methylation to influence the expression of the gene are largely unknown. The majority of studies of others only examined a limited number of genetic regions and show contradicting results (Crider et al. 2012). Results from the current study reflect pooled data from DNA methylation in different genomic regions. So far the biological basis and implications of these altered profiles remain unknown. Fetal growth and neuronal development are characterized by widespread cell division. Inadequate folate status led to several types of birth defects, including certain heart defect, limb malformations, and in particular neural tube defects. Pangilinan et al. (2012) reported common genetic variants in 82 candidate genes 
selected from 1-C-pathway, including MTHFR, as risk factors for neural tube defects. Other variants are involved in, for example, choline metabolism, reabsorption of vitamin B12, and mitochondrial folate transport. To date, evidence from literature suggested that low folate status is associated with decreases in global DNA methylation, which has been associated with adverse health outcomes, in particular cancer (Crider et al. 2012). However, as yet it is unknown how specific genomic regions respond to lower or higher folate intakes.

\section{Conclusion}

This study suggests that the maternal MTHFR C677T genotype is a determinant of the DNA methylation status associated with some genes of the epigenome of the newborn. Confounding factors including maternal socio-demographic factors and pregnancy characteristics, however, attenuated the association between maternal folate deficiency and lower DNA methylation in newborns. Therefore, further research to confirm our results and to investigate the influence of the expression of these genes and the implications for health is recommended.

\section{Supplementary data}

This is linked to the online version of the paper at http://dx.doi. org/10.1530/REP-14-0260.

\section{Declaration of interest}

The authors declare that there is no conflict of interest that could be perceived as prejudicing the impartiality of the research reported.

\section{Funding}

The Generation R Study is made possible by financial support from the Erasmus MC, University Medical Center Rotterdam; Erasmus University Rotterdam; and The Netherlands Organization for Health Research and Development (ZonMw) 'Geestkracht' programe (10.000.1003). N H van Mil was supported by an additional grant from the Sophia Foundation for Medical Research (SSWO grant number 268).

\section{Acknowledgements}

The Generation R Study is conducted by the Erasmus MC, University Medical Center Rotterdam in close collaboration with the Faculty of Social Sciences of the Erasmus University Rotterdam, the Municipal Health Service Rotterdam area, the Rotterdam Homecare Foundation, and the Stichting Trombosedienst \& Artsenlaboratorium Rijnmond (STAR), Rotterdam. The authors gratefully acknowledge the contribution of all participants, general practitioners, hospitals, midwives, and pharmacies in Rotterdam.

\section{References}

Barouki R, Gluckman PD, Grandjean P, Hanson M \& Heindel JJ 2012 Developmental origins of non-communicable disease: implications for research and public health. Environmental Health 11 42. (doi:10.1186/ 1476-069X-11-42)

Bell JT, Pai AA, Pickrell JK, Gaffney DJ, Pique-Regi R, Degner JF, Gilad Y \& Pritchard JK 2011 DNA methylation patterns associate with genetic and gene expression variation in HapMap cell lines. Genome Biology 12 R10. (doi:10.1186/gb-2011-12-1-r10)

Bergen NE, Jaddoe VW, Timmermans S, Hofman A, Lindemans J, Russcher H, Raat H, Steegers-Theunissen RP \& Steegers EA 2012 Homocysteine and folate concentrations in early pregnancy and the risk of adverse pregnancy outcomes: the Generation R Study. BJOG: an International Journal of Obstetrics and Gynaecology 119 739-751. (doi:10.1111/j.1471-0528.2012.03321.x)

Bouwland-Both MI, van Mil NH, Stolk L, Eilers PH, Verbiest MM, Heijmans BT, Tiemeier H, Hofman A, Steegers EA, Jaddoe VW \& Steegers-Theunissen RP 2013 DNA methylation of IGF2DMR and H19 is associated with fetal and infant growth: the generation R study. PLoS One 8 e81731. (doi: 10.1371/journal.pone.0081731)

Burton P, Gurrin L \& Sly P 1998 Extending the simple linear regression model to account for correlated responses: an introduction to generalized estimating equations and multi-level mixed modelling. Statistics in Medicine 17 1261-1291. (doi:10.1002/(SICI)10970258(19980615)17:11 < 1261::AID-SIM846>3.0.CO;2-Z)

Cortessis VK, Thomas DC, Levine AJ, Breton CV, Mack TM, Siegmund KD, Haile RW \& Laird PW 2012 Environmental epigenetics: prospects for studying epigenetic mediation of exposure-response relationships. Human Genetics 131 1565-1589. (doi:10.1007/s00439-012-1189-8)

Crider KS, Zhu JH, Hao L, Yang QH, Yang TP, Gindler J, Maneval DR, Quinlivan EP, Li Z, Bailey LB et al. 2011 MTHFR 677C $\rightarrow$ T genotype is associated with folate and homocysteine concentrations in a large, population-based, double-blind trial of folic acid supplementation. American Journal of Clinical Nutrition 93 1365-1372. (doi:10.3945/ ajcn.110.004671)

Crider KS, Yang TP, Berry RJ \& Bailey LB 2012 Folate and DNA methylation: a review of molecular mechanisms and the evidence for folate's role. Advances in Nutrition 3 21-38. (doi:10.3945/an.111.000992)

Fekete K, Berti C, Trovato M, Lohner S, Dullemeijer C, Souverein OW, Cetin I \& Decsi T 2012 Effect of folate intake on health outcomes in pregnancy: a systematic review and meta-analysis on birth weight, placental weight and length of gestation. Nutrition Journal 1175. (doi:10.1186/1475-2891-11-75)

Frosst P, Blom HJ, Milos R, Goyette P, Sheppard CA, Matthews RG, Boers GJ, den Heijer M, Kluijtmans LA, van den Heuvel LP et al. 1995 A candidate genetic risk factor for vascular disease: a common mutation in methylenetetrahydrofolate reductase. Nature Genetics 10 111-113. (doi:10.1038/ng0595-111)

Ghosh S, Yates AJ, Fruhwald MC, Miecznikowski JC, Plass C \& Smiraglia D 2010 Tissue specific DNA methylation of CpG islands in normal human adult somatic tissues distinguishes neural from non-neural tissues. Epigenetics 5 527-538. (doi:10.4161/epi.5.6.12228)

Gilbody S, Lewis S \& Lightfoot T 2007 Methylenetetrahydrofolate reductase (MTHFR) genetic polymorphisms and psychiatric disorders: a HuGE review. American Journal of Epidemiology 165 1-13. (doi:10.1093/aje/ kwj347)

Glossop JR, Nixon NB, Emes RD, Haworth KE, Packham JC, Dawes PT, Fryer AA, Mattey DL \& Farrell WE 2013 Epigenome-wide profiling identifies significant differences in DNA methylation between matchedpairs of T- and B-lymphocytes from healthy individuals. Epigenetics 8 1188-1197. (doi:10.4161/epi.26265)

Gueant JL, Namour F, Gueant-Rodriguez RM \& Daval JL 2013 Folate and fetal programming: a play in epigenomics? Trends in Endocrinology and Metabolism 24 279-289. (doi:10.1016/j.tem.2013.01.010)

Haggarty P, Hoad G, Campbell DM, Horgan GW, Piyathilake C \& McNeill G 2013 Folate in pregnancy and imprinted gene and repeat element methylation in the offspring. American Journal of Clinical Nutrition 97 94-99. (doi:10.3945/ajcn.112.042572)

Hague WM 2003 Homocysteine and pregnancy. Best Practice \& Research. Clinical Obstetrics \& Gynaecology 17 459-469. (doi:10.1016/S15216934(03)00009-9) 
Heijmans BT, Tobi EW, Stein AD, Putter H, Blauw GJ, Susser ES, Slagboom PE \& Lumey LH 2008 Persistent epigenetic differences associated with prenatal exposure to famine in humans. PNAS $\mathbf{1 0 5}$ 17046-17049. (doi:10.1073/pnas.0806560105)

Herzog E, Galvez J, Roks A, Stolk L, Verbiest M, Eilers P, Cornelissen J, Steegers E \& Steegers-Theunissen R 2013 Tissue-specific DNA methylation profiles in newborns. Clinical Epigenetics 5 8. (doi:10. 1186/1868-7083-5-8)

Jacob RA, Gretz DM, Taylor PC, James SJ, Pogribny IP, Miller BJ, Henning SM \& Swendseid ME 1998 Moderate folate depletion increases plasma homocysteine and decreases lymphocyte DNA methylation in postmenopausal women. Journal of Nutrition 128 1204-1212.

Jacques PF, Bostom AG, Williams RR, Ellison RC, Eckfeldt JH, Rosenberg IH, Selhub J \& Rozen R 1996 Relation between folate status, a common mutation in methylenetetrahydrofolate reductase, and plasma homocysteine concentrations. Circulation 93 7-9. (doi:10.1161/01.CIR. 93.1.7)

Jacques PF, Kalmbach R, Bagley PJ, Russo GT, Rogers G, Wilson PW, Rosenberg IH \& Selhub J 2002 The relationship between riboflavin and plasma total homocysteine in the Framingham Offspring cohort is influenced by folate status and the C677T transition in the methylenetetrahydrofolate reductase gene. Journal of Nutrition 132 283-288.

Jaddoe VW, van Duijn CM, Franco $\mathrm{OH}$, van der Heijden $\mathrm{AJ}$, van lizendoorn $\mathrm{MH}$, de Jongste JC, van der Lugt A, Mackenbach JP, Moll HA, Raat H et al. 2012 The Generation R Study: design and cohort update 2012. European Journal of Epidemiology 27 739-756. (doi:10. 1007/s10654-012-9735-1)

Joubert BR, Haberg SE, Nilsen RM, Wang X, Vollset SE, Murphy SK, Huang Z, Hoyo C, Midttun O, Cupul-Uicab LA et al. 2012 450K epigenome-wide scan identifies differential DNA methylation in newborns related to maternal smoking during pregnancy. Environmental Health Perspectives 120 1425-1431. (doi:10.1289/ehp.1205412)

Kim MW, Hong SC, Choi JS, Han JY, Oh MJ, Kim HJ, Nava-Ocampo A \& Koren G 2012 Homocysteine, folate and pregnancy outcomes. Journal of Obstetrics and Gynaecology 32 520-524. (doi:10.3109/01443615. 2012.693984)

McGowan PO, Sasaki A, D'Alessio AC, Dymov S, Labonte B, Szyf M, Turecki G \& Meaney MJ 2009 Epigenetic regulation of the glucocorticoid receptor in human brain associates with childhood abuse. Nature Neuroscience 12 342-348. (doi:10.1038/nn.2270)

McKay JA, Wong YK, Relton CL, Ford D \& Mathers JC 2011 Maternal folate supply and sex influence gene-specific DNA methylation in the fetal gut. Molecular Nutrition \& Food Research 55 1717-1723. (doi:10.1002/mnfr. 201100150)

McKay JA, Groom A, Potter C, Coneyworth LJ, Ford D, Mathers JC \& Relton CL 2012 Genetic and non-genetic influences during pregnancy on infant global and site specific DNA methylation: role for folate gene variants and vitamin B12. PLoS ONE 7 e33290. (doi:10.1371/journal. pone.0033290)

Mulligan CJ, D'Errico NC, Stees I \& Hughes DA 2012 Methylation changes at NR3C1 in newborns associate with maternal prenatal stress exposure and newborn birth weight. Epigenetics 7 853-857. (doi:10.4161/epi.21180)

Niculescu MD \& Zeisel SH 2002 Diet, methyl donors and DNA methylation: interactions between dietary folate, methionine and choline. Journal of Nutrition 132 2333S-2335S.

Obeid R, Munz W, Jager M, Schmidt W \& Herrmann W 2005 Biochemical indexes of the $\mathrm{B}$ vitamins in cord serum are predicted by maternal $\mathrm{B}$ vitamin status. American Journal of Clinical Nutrition 82 133-139.

Oberlander TF, Weinberg J, Papsdorf M, Grunau R, Misri S \& Devlin AM 2008 Prenatal exposure to maternal depression, neonatal methylation of human glucocorticoid receptor gene (NR3C1) and infant cortisol stress responses. Epigenetics 3 97-106. (doi:10.4161/epi.3.2.6034)

Obermann-Borst SA, van Driel LM, Helbing WA, de Jonge $R$, Wildhagen MF, Steegers EA \& Steegers-Theunissen RP 2011 Congenital heart defects and biomarkers of methylation in children: a case-control study. European Journal of Clinical Investigation 41 143-150. (doi:10. 1111/j.1365-2362.2010.02388.x)

Pangilinan F, Molloy AM, Mills JL, Troendle JF, Parle-McDermott A, Signore C, O'Leary VB, Chines P, Seay JM, Geiler-Samerotte K et al. 2012 Evaluation of common genetic variants in 82 candidate genes as risk factors for neural tube defects. BMC Medical Genetics 1362 . (doi:10.1186/1471-2350-13-62)
Philibert RA, Sandhu H, Hollenbeck N, Gunter T, Adams W \& Madan A 2008 The relationship of 5HTT (SLC6A4) methylation and genotype on mRNA expression and liability to major depression and alcohol dependence in subjects from the lowa Adoption Studies. American Journal of Medical Genetics. Part B, Neuropsychiatric Genetics 147B 543-549. (doi:10.1002/ajmg.b.30657)

van der Put NM, van den Heuvel LP, Steegers-Theunissen RP, Trijbels FJ, Eskes TK, Mariman EC, den Heyer M \& Blom HJ 1996 Decreased methylene tetrahydrofolate reductase activity due to the $677 \mathrm{C} \rightarrow \mathrm{T}$ mutation in families with spina bifida offspring. Journal of Molecular Medicine 74 691-694. (doi:10.1007/s001090050073)

van Mil N, Steegers-Theunissen RP, Bouwland-Both MI, Verbiest MM, Rijlaarsdam J, Hofman A, Steegers EA, Heijmans BT, Jaddoe VW, Verhulst FC, Stolk L, Eilers PH, Uitterlinden AG \& Tiemeier H 2014 DNA methylation profiles at birth and child ADHD symptoms. Journal of Psychiatric Research 49 51-59. (doi:10.1016/j.jpsychires.2013.10.017)

Radtke KM, Ruf M, Gunter HM, Dohrmann K, Schauer M, Meyer A \& Elbert T 2011 Transgenerational impact of intimate partner violence on methylation in the promoter of the glucocorticoid receptor. Translational Psychiatry 1 e21. (doi:10.1038/tp.2011.21)

Rampersaud GC, Kauwell GP, Hutson AD, Cerda JJ \& Bailey LB 2000 Genomic DNA methylation decreases in response to moderate folate depletion in elderly women. American Journal of Clinical Nutrition $\mathbf{7 2}$ 998-1003.

Reinius LE, Acevedo N, Joerink M, Pershagen G, Dahlen SE, Greco D, Soderhall C, Scheynius A \& Kere J 2012 Differential DNA methylation in purified human blood cells: implications for cell lineage and studies on disease susceptibility. PLoS ONE 7 e41361. (doi:10.1371/journal.pone. 0041361)

Roza SJ, van Batenburg-Eddes T, Steegers EA, Jaddoe VW, Mackenbach JP, Hofman A, Verhulst FC \& Tiemeier H 2010 Maternal folic acid supplement use in early pregnancy and child behavioural problems: the Generation R Study. British Journal of Nutrition 103 445-452. (doi:10.1017/S0007114509991954)

Shames DS, Minna JD \& Gazdar AF 2007 DNA methylation in health, disease, and cancer. Current Molecular Medicine 7 85-102. (doi:10. 2174/156652407779940413)

Shelnutt KP, Kauwell GP, Gregory JF III, Maneval DR, Quinlivan EP, Theriaque DW, Henderson GN \& Bailey LB 2004 Methylenetetrahydrofolate reductase $677 \mathrm{C} \rightarrow T$ polymorphism affects DNA methylation in response to controlled folate intake in young women. Journal of Nutritional Biochemistry 15 554-560. (doi:10.1016/j.jnutbio.2004.04.003)

Simpson JL, Bailey LB, Pietrzik K, Shane B \& Holzgreve W 2010 Micronutrients and women of reproductive potential: required dietary intake and consequences of dietary deficiency or excess. Part I - folate, vitamin B12, vitamin B6. Journal of Maternal-Fetal \& Neonatal Medicine 23 1323-1343. (doi:10.3109/14767051003678234)

Sinclair KD, Allegrucci C, Singh R, Gardner DS, Sebastian S, Bispham J, Thurston A, Huntley JF, Rees WD, Maloney CA et al. 2007 DNA methylation, insulin resistance, and blood pressure in offspring determined by maternal periconceptional B vitamin and methionine status. PNAS 104 19351-19356. (doi:10.1073/pnas.0707258104)

Smith AD, Kim YI \& Refsum H 2008 Is folic acid good for everyone? American Journal of Clinical Nutrition 87 517-533.

Steegers-Theunissen RP, Obermann-Borst SA, Kremer D, Lindemans J, Siebel C, Steegers EA, Slagboom PE \& Heijmans BT 2009 Periconceptional maternal folic acid use of 400 microg per day is related to increased methylation of the IGF2 gene in the very young child. PLoS ONE 4 e7845. (doi:10.1371/journal.pone.0007845)

Steegers-Theunissen RP, Twigt J, Pestinger V \& Sinclair KD 2013 The periconceptional period, reproduction and long-term health of offspring: the importance of one-carbon metabolism. Human Reproduction Update 19 640-655. (doi:10.1093/humupd/dmt041)

Talens RP, Boomsma DI, Tobi EW, Kremer D, Jukema JW, Willemsen G, Putter H, Slagboom PE \& Heijmans BT 2010 Variation, patterns, and temporal stability of DNA methylation: considerations for epigenetic epidemiology. FASEB Journal 24 3135-3144. (doi:10.1096/fj.09150490)

Tobi EW, Lumey LH, Talens RP, Kremer D, Putter H, Stein AD, Slagboom PE \& Heijmans BT 2009 DNA methylation differences after exposure to prenatal famine are common and timing- and sex-specific. Human Molecular Genetics 18 4046-4053. (doi:10.1093/hmg/ddp353) 
Turner JD \& Muller CP 2005 Structure of the glucocorticoid receptor (NR3C1) gene $5^{\prime}$ untranslated region: identification, and tissue distribution of multiple new human exon 1. Journal of Molecular Endocrinology 35 283-292. (doi:10.1677/jme.1.01822)

van Uitert EM, van der Elst-Otte $\mathrm{N}$, Wilbers J, Exalto N, Willemsen SP, Eilers PH, Koning AH, Steegers EA \& Steegers-Theunissen RP 2013 Periconception maternal characteristics and embryonic growth trajectories: the Rotterdam Predict study. Human Reproduction 28 3188-3196. (doi:10.1093/humrep/det375)

Verburg BO, Steegers EA, De Ridder M, Snijders RJ, Smith E, Hofman A, Moll HA, Jaddoe VW \& Witteman JC 2008 New charts for ultrasound dating of pregnancy and assessment of fetal growth: longitudinal data from a population-based cohort study. Ultrasound in Obstetrics \& Gynecology 31 388-396. (doi:10.1002/uog.5225)

Walter S \& Tiemeier H 2009 Variable selection: current practice in epidemiological studies. European Journal of Epidemiology 24 733-736. (doi:10.1007/s10654-009-9411-2)

Waterland RA \& Jirtle RL 2004 Early nutrition, epigenetic changes at transposons and imprinted genes, and enhanced susceptibility to adult chronic diseases. Nutrition 20 63-68. (doi:10.1016/j.nut.2003.09.011)

Waterland RA \& Michels KB 2007 Epigenetic epidemiology of the developmental origins hypothesis. Annual Review of Nutrition 27 363-388. (doi:10.1146/annurev.nutr.27.061406.093705)
Waterland RA, Dolinoy DC, Lin JR, Smith CA, Shi X \& Tahiliani KG 2006 Maternal methyl supplements increase offspring DNA methylation at Axin Fused. Genesis 44 401-406. (doi:10.1002/dvg.20230)

Weggemans RM, Schaafsma G, Kromhout D \& Health Council of The Netherlands 2009 Toward an optimal use of folic acid: an advisory report of the Health Council of The Netherlands. European Journal of Clinical Nutrition 63 1034-1036. (doi:10.1038/ejcn.2009.2)

Wong CC, Caspi A, Williams B, Craig IW, Houts R, Ambler A, Moffitt TE \& Mill J 2010 A longitudinal study of epigenetic variation in twins. Epigenetics 5 516-526. (doi:10.4161/epi.5.6.12226)

Zhang D, Cheng L, Badner JA, Chen C, Chen Q, Luo W, Craig DW, Redman M, Gershon ES \& Liu C 2010 Genetic control of individual differences in gene-specific methylation in human brain. American Journal of Human Genetics 86 411-419. (doi:10. 1016/j.ajhg.2010.02.005)

Received 20 May 2014

First decision 11 June 2014

Revised manuscript received 6 August 2014

Accepted 18 September 2014 